\title{
How to write a case report? Or...not write at all?
}

\author{
Bir olgu sunumu nasıl yazılmalı? Ya da hiç yazılmamalı mı?
}

\author{
A. Erdem Bagatur, MD., ${ }^{1}$ Merter Yalçınkaya, MD. ${ }^{2}$ \\ ${ }^{1}$ Department of Orthopedics and Traumatology, Medicana International Istanbul Hospital, İstanbul, Turkey \\ 2Department of Orthopedics and Traumatology, Metin Sabanci Baltalimani Bone Diseases Training and Research Hospital, İstanbul, Turkey
}

Case report is the oldest and the best-known type of publication in medicine. Many original observations, recognition of new diseases, novel diagnostic and therapeutic methods, unusual forms of common diseases, and complications were first published as case reports. Case reports have become a standard and indispensable part of the medical literature. However, getting a case report published in a respectable journal was never more troublesome. In this essay, pearls and pitfalls as well as the importance of writing a case report for a journal have been further discussed.

Keywords: Case reports; peer review; publishing; research.

Always note and record the unusual...Publish it. Place it on permanent record as a short, concise note. Such communications are always of value.

\section{William Osler}

Case report is the oldest and best-known type of publication in medicine. Many original observations, recognition of new diseases, novel diagnostic and therapeutic methods, unusual forms of common diseases, and complications were first published as case reports. Many scholars who publish usually have at least one case report published and many scholars who read scientific publications read case reports interestedly. Case reports have become a standard and indispensable part of the medical literature.

Getting a case report published in a respectable journal, however, was never more troublesome. We believe that journals should never abandon publishing case reports. A case report does not provide level I evidence, but it is the unique means to convey some
Olgu sunumu tıpta en eski ve en iyi bilinen yayın türüdür. Çok sayıda orijinal gözlem, tanınan yeni hastalıklar, yeni geliştirilen tanısal ve tedavisel yöntemler, yaygın hastalıkların olağandışı şekilleri ve komplikasyonlar ilk olgu sunumu olarak yayınlanmıştır. Olgu sunumları tıbbi literatürün standart ve vazgeçilmez bir parçası olmuştur. Öte yandan, bir olgu sunumunu saygın bir dergide yayınlatmak hiç bu kadar zor olmamıştır. Bu yazıda, bir dergi için olgu sunumu yazmanın artıları ve eksileriyle beraber önemi ayrıntılı olarak ele alınmiştır.

Anahtar sözcükler: Olgu sunumları; hakem denetimi; yayıncılık; araştırma.

crucial piece of information. Take, for example, the case report published recently in Clinical Orthopedics and Related Research, about a patient who had had pulmonary cement embolization after vertebroplasty requiring pulmonary resection and an embolectomy through a sternotomy using cardiopulmonary bypass and still left with ongoing effects of the pulmonary cement embolism. ${ }^{[1]}$ How could we have ever learned about this devastating complication and the way to handle it if it were not with this case report?

Many orthopedic surgery journals have sections reserved for case reports. However, some prominent journals with high impact factors such as The Bone $\mathcal{E}$ Joint Journal, ${ }^{[2]}$ and International Orthopaedics do not publish case reports any more. ${ }^{[3]}$ On the other hand, other important journals such as Clinical Orthopedics and Related Research, ${ }^{[4]}$ Journal of Hand Surgery, ${ }^{[5]}$ and Foot and Ankle International, ${ }^{[6]}$ publish very few case reports and indicate this in 'instructions to authors'.

- Received: August 21, 2014 Accepted: October 14, 2014

- Correspondence: A. Erdem Bagatur, M.D. Medicana International Istanbul Hospital Ortopedi ve Travmatoloji Kliniği, 34520 Beylikdüzü, İstanbul, Turkey. Tel: +90 212 - 8677500 Fax: +90 212-867 7672 e-mail: erdembagatur@gmail.com 
Nevertheless, there are many authors all over the world who are very enthusiastic to publish case reports. Furthermore, writing a case report is an excellent learning experience for young authors in regard of writing scientific texts, and it may also lead to produce more scholarly work and research. ${ }^{[7]}$ In the recent years, many journals such as Journal of Medical Case Reports, ${ }^{[8]}$ Cases Journal, ${ }^{[9]}$ International Journal of Surgery Case Reports, ${ }^{[10]}$ American Journal of Case Reports, ${ }^{[11]}$ Journal of Case Reports, ${ }^{[12]}$ which publish case reports only were founded. Naturally, Journal of Orthopaedic Case Reports and Case Reports in Orthopedics which publish orthopedic case reports only appeared soon after. ${ }^{[13,14]}$

Journals which no longer publish or publish very few case reports claim that they receive far more case reports than space allows for publication. However, this is not always the case, as some journals consider the level of evidence for case reports as low, ${ }^{[6]}$ and some consider that case reports do not have any level of evidence at all. ${ }^{[15,16]}$ While case-series have a level IV evidence, case reports are not mentioned at all in the list of Oxford Centre for Evidence-Based Medicine. ${ }^{[17]}$ Some journals ask the authors to assign a level of evidence when they submit an article; Journal of Shoulder and Elbow Surgery and The Journal of Bone and Joint Surgery do not ask for a level for case reports (in other words, these journals assume that case reports do not have a level of evidence), ${ }^{[15,16]}$ Foot and Ankle International indicates that case reports must be assigned Level $\mathrm{V}^{[6]}$ It is known that case reports are cited less often, therefore journals publishing too many case reports will have low impact factor values in the end. ${ }^{[18]}$ On the other hand, the likelihood of being cited is higher for articles published in journals with high impact factor values and this fact causes a vicious cycle for case reports, leading these journals either to not publish or publish very few case reports.

Could it be that journals cannot find case reports worth publishing? Clinical Orthopedics and Related Research and Journal of Hand Surgery indicate that they "accept those of exceptional teaching value" and "do not accept cases in which two entities are associated since conditions may occur coincidentally, rather than causally." ${ }^{\prime 4,5]}$ Furthermore, Clinical Orthopedics and Related Research indicates that they "also do not typically consider those situations for which the focus of the report is treatment since the success or failure of a treatment in a single case would not provide a basis for generalizing." ${ }^{\prime[4]}$ Foot and Ankle International indicates that "case reports must either offer new information that has not been published before, offer completely new information or information that will change the current practice patterns. Entities that are unique in and of themselves, bizarre, or common will not be accepted as case reports." ${ }^{[6]}$

Is this the reason why we cannot get our very well illustrated, interesting cases with very good outcomes that have striking radiographs and magnetic resonance images published in prominent journals? What should be done in this case? Should one give up trying to get a case report published under these circumstances?

There are important clues about writing a case report in an editorial in The Journal of Shoulder and Elbow Surgery. ${ }^{[19]}$ One issue stressed is that case reports should not only present important, new, and original information, but they should also change the way physicians practice and improve the treatment of patients. The editor mentions a case report published in The Journal of Bone Joint Surgery which he believes should be the prototype for case reports. ${ }^{[20]}$ The case report was about a patient who died during shoulder arthroscopy due to an air embolism that was attributed to air within the arthroscopy bags. The surgeons have decided to publish this sad case because of its instructive features and prevent such future problems by aspirating all air from within the arthroscopy fluid bags as recommended in the case report which became to be practiced widely. Thus the purpose of publishing a case report was fulfilled by reporting a previously unknown complication, changing the practice of shoulder arthroscopy, and improving the treatment of patients by making shoulder arthroscopy safer.

What a case report should not be was also emphasized. First of all, like any article, it should be original. ${ }^{[21]}$ It is pointless to report on a case if it had been reported before, even only a few times. Secondly, it should be important; it is nonsense to report variants of already well-described cases. Injury combinations which are together by coincidence are not important as all will be fixed in the usual manner anyway. Treatment methods which were not performed before and which will probably never be performed again are not worth reporting. A recently rejected case report of arthroscopic treatment of a mid-shaft clavicle fracture was given as an example and the editor makes fun of the authors, "We are very proud of you, but we are not going to publish it."

On the other hand, the editor of Cases Journal advocates a different point of view. ${ }^{[22,23]}$ He claims that any case report that is authentic, understandable, and ethical deserves to be published as it will help both the authors and the readers to learn and it does 
not have to be original or important. Health care is actually an accumulation of case reports. However, these assumptions have no effect on policy-making decisions of the prominent journals with high impact factors.

Alongside of this on-going controversy, the number of case reports in medical journals is growing, but their quality is uneven and those lacking reporting guidelines are insufficient to convey any information that may guide clinical practice. ${ }^{[2]}$ To overcome this issue of reporting guidelines for case reports through a consensus-based process, the CAse REporting (CARE) guidelines were developed with a 13-item checklist providing a framework to meet the need for completeness and transparency for case reports. ${ }^{[24]}$

Case reports are definitely a time-honored, important, and integral part of the medical literature. ${ }^{[7]}$ What to avoid is more important when writing a case report. A case report is a great learning experience for the author as well as the reader. Go for it!

\section{Declaration of conflicting interests}

The authors declared no conflicts of interest with respect to the authorship and/or publication of this article.

\section{Funding}

The authors received no financial support for the research and/or authorship of this article.

\section{REFERENCES}

1. Rothermich MA, Buchowski JM, Bumpass DB, Patterson GA. Pulmonary cement embolization after vertebroplasty requiring pulmonary wedge resection. Clin Orthop Relat Res 2014;472:1652-7.

2. Available from: http://www.bjj.boneandjoint.org.uk/site/ menubar/info_authors.xhtml. [Accessed: May 2014]

3. Available from: http://www.springer.com/medicine/ orthopedics/journal/264. [Accessed: May 2014]

4. Available from: http://www.clinorthop.org. [Accessed: May 2014]

5. Available from: http://www.jhandsurg.org/authorinfo. [Accessed: May 2014]

6. Available from: http://www.sagepub.com/upmdata/49175_FAI_Submission_Guidelines.pdf. [Accessed: May 2014]

7. Rison RA. A guide to writing case reports for the Journal of Medical Case Reports and BioMed Central Research Notes. J Med Case Rep 2013;7:239.

8. Available from: http://www.jmedicalcasereports.com. [Accessed: May 2014]

9. Available from: http://www.casesjournal.com. [Accessed: May 2014]

10. Available from: http://www.journals.elsevier.com/ international-journal-of-surgery-case-reports. [Accessed: May 2014]

11. Available from: http://www.amjcaserep.com. [Accessed: May 2014]

12. Available from: http://www.casereports.in. [Accessed: May 2014]

13. Available from: http://www.jocr.co.in. [Accessed: May 2014]

14. Available from: http://www.hindawi.com/crim/ orthopedics. [Accessed: May 2014]

15. Available from: http:// www.jbjs.org/public/ instructionsauthors.aspx. [Accessed: May 2014]

16. Available from: http://www.jshoulderelbow.org/article/ S1058-2746(13)00146-8/fulltext. [Accessed: May 2014]

17. Available from: http://www.cebm.net/?o=1025 [Accessed: May 2014]

18. Agha R, Rosin RD. Time for a new approach to case reports. Int J Surg Case Rep 2010;1:1-3.

19. Mallon B. Case reports. J Shoulder Elbow Surg 2013;22:723-4.

20. Zmistowski B, Austin L, Ciccotti M, Ricchetti E, Williams G Jr. Fatal venous air embolism during shoulder arthroscopy: a case report. J Bone Joint Surg [Am] 2010;92:2125-7.

21. Atik OS. How to write a scientific article?. [Article in Turkish] Eklem Hastalik Cerrahisi 2012;23:60.

22. Smith R. Why do we need Cases Journal? Cases J 2008;1:1.

23. Smith R. The policies of Cases Journal. Cases J 2008;1:2.

24. Gagnier JJ, Riley D, Altman DG, Moher D, Sox H, Kienle G. The CARE guidelines: consensus-based clinical case reporting guideline development. Dtsch Arztebl Int 2013;110:603-8. 